\title{
Food Additives and Hypersensitivity: A Review
}

\author{
Eram S. Rao, Rizwana, C. Lalmuanpuia*, G. Aparajita and K. Prateek \\ Deptartment of Food Technology, Bhaskaracharya College of Applied Sciences, \\ University of Delhi, India \\ *Corresponding author
}

\section{Keywords}

Hypersensitivity, Food additives, Urticaria, Atopic constitutions, Rhinitis

\section{Article Info}

\section{Accepted:}

15 January 2021 Available Online: 10 February 2021
Food additives are added to processed and packaged foods to perform a wide range of technical functions. There are thousands of additives approved for use in foods that are classified according to the functions they perform such as preservatives, sweeteners, colouring agents, stabilizers, flavourings, antioxidants etc. However, some of them have been reported to cause adverse reactions or hypersensitivities in many individuals like urticaria, asthma, dermatitis, oedema, asthma and anaphylaxis. The best strategic approach for management of food additive hypersensitivity is complete avoidance of the offending foods. Adequate information about the food additives, along with the types of food in which it may be found and the various terms that are used to identify them on an ingredient statement is crucial. The responsibility of a food processor is to declare all the information regarding the food additives on the label of food products. This paper provides a brief summary on food additives implicated in hypersensitivities.

\section{Introduction}

Food additives are "substances intentionally added to preserve, maintain or improve its safety, freshness, taste, texture, or appearance of foods". They are added to food at any stage of production, processing, treatment, packaging, or storage. For centuries, food additives derived from natural sources have been used to perform variety of technical functions, later synthetic food additives were introduced and are now commonly used. Presently, there are more than 3000 food additives listed by the FDA. They are classified according to the functions they perform, i.e. as preservatives, antioxidants, sweeteners, colourants, flavourings, flavour enhancers, fat replacers, nutrients, emulsifiers, stabilizers and thickeners, binders, texturizers, $\mathrm{pH}$ control agents and acidulants, leavening 
agents, anti-caking agents, humectants etc. Prior to their approval, any novel food additive mandatorily undergoes extensive risk assessment and safety evaluation studies. Moreover, any approved additive also at any given time point having questionable safety issues is also reassessed. There are about a thousand substances added to foods that are "Generally Recognized As Safe" (GRAS) by experts and are exempted from the usual tolerance requirements (Neltner et al., (2011). However, there are individuals who are sensitive to certain food additives particularly children, immuno-compromised individuals, people with inherited metabolic disorders, and people with different capacities to metabolize xenobiotics.

Food hypersensitivity is defined as an adverse reaction to food or a food additive and can be mediated by two different mechanisms: immunologic and non-immunologic. Only a few food additives have been shown to cause immunologic reactions while adverse effects due to various pharmacological or other mechanisms are much more common. Since most of the food additives are non-proteins, their adverse reactions are generally considered as 'hypersensitivity' or 'intolerance'. Many authors avoid the use of the term 'allergy' in connection with adverse reactions due to food additives. Common signs and symptoms of hypersensitivity to food additive include urticaria, itching, angioneurotic oedema, atopic constitutions, rhinitis and asthma. Total avoidance is the only solution for individuals who have adverse reaction to any particular food additive.

\section{Prevalence of hypersensitivity to food additives}

Only a few authors have reported the prevalence of adverse reactions to food additives. These studies reported that the prevalence of these reactions is rather low, contrary to insights of the general public. In adults it is estimated to be less than $1 \%$, while children seem to be a little more sensitive (12\%) (Madsen 1994; Feketea and Tsabouri 2017). Overall, it has been observed that adverse reactions to food additives affect about $0.01 \%$ to $0.23 \%$ of the general population but the prevalence may be higher in patients with atopic disease (2\%-7\%) (Randhawa, 2009). Table 1 shows the key studies conducted on prevalence of hypersensitivity to food additives.

\section{Food additives implicated in hypersensitivities}

Amongst the vast range of food additives permitted for use, relatively few have been identified as causing significant adverse reactions. Moreover, not everyone is affected by the ingestion of food additives, only a few experience severe reactions on intake of these. Food additives which have been prone to hypersensitive reactions with few case studies are discussed below (Table 4). These are implicated in causing reactions involving skin such as urticaria, itching, flushing, and gastrointestinal respiratory reactions.

\section{Antioxidants}

\section{Butylated hydroxy anisole and butylated hydroxy toluene}

Antioxidants are substances that inhibit or interfere with the free radical oxidation in fats and oils. Butylated Hydroxy Anisole and Butylated Hydroxy Toluene (BHA \& BHT) are phenolic antioxidants that are widely used in preventing rancidity in foods high in fats and oils. Besides providing stability, they also prevent discolouration in food that may occur due to oxidation (Botterweck et al., 2000).

There is conflicting evidence available in associating BHA or BHT to hypersensitivity 
reactions. In a study conducted by Rajan et al., 2014 of 100 patients with chronic urticaria with and without histories of food additive sensitivity using both single-blind and doubleblind placebo (DBPC) challenges, BHA and BHT at doses of $250 \mathrm{mg}$ failed to provoke urticarial flares. However, BHA and BHT were among a mixture of 22 food additives that caused worsening of atopic dermatitis in 6 out of 15 patients, but the culprit additives remain unidentified (Worm et al., 2000).

BHA and BHT have been shown to cause an increase in the symptoms of urticaria, a form of skin rash with red itchy and bumpy skin, rhinitis, asthma etc. Metcalfe et al., (2008) have reported intolerance reactions like urticaria and nasal congestion upon ingestion of 250-500mg of BHA \& BHT amongst subjects. In another study it was seen that two individuals experienced exacerbations in their chronic idiopathic urticaria after ingestion of food containing antioxidants BHA \& BHT. A reduction in the severity of urticaria was noticed when the patients were prescribed a BHA \& BHT free diet (Goodman et al., 1990). Similarly, in a study, seven patients with asthma, vasomotor rhinitis or combination of both were suspected to be sensitive to BHA \& BHT. On testing them with capsules of BHA \& BHT, symptoms of vasomotor rhinitis, headache, flushing, asthma, conjunctival suffusion, dull retrosternal pain radiating to the back, increased (Allen et al., 1987).

\section{Gallates}

Gallates, especially propyl gallates are usually used in combination with BHA or BHT, providing improved storage stability and carry-through protection to fats and oil rich foods. Kahn et al., (1974) have reported the ability of gallates to induce contact sensitization and skin allergies like pruritus, redness and erythema. It is seen to cause hypersensitivity reactions like dermatitis, angioedema, and inflammation. In a study, when patch test was conducted forty-six people were tested positive for contact dermatitis mainly cheilitis (inflammation and red patches around the mouth) (63\%) and dermatitis in hands (28.26\%). Octyl gallate commonly added to bakery products was responsible for $15.2 \%$ adverse reactions. Similarly, propyl gallate was implicated in $56 \%$ of the patients being sensitive to gallates, fragrances and flavourings (Gultekin et al., 2013). Apart from eczema, a 44-year-old man was found to develop angioedema of lips after he consumed a packaged food containing gallates (Melgares et al., 2007). The symptoms in each of these studies were found to subside after eliminating the consumption of food products containing gallates.

\section{Food colours}

Colors are often added to foods to make them more appealing and to compensate any colour losses during food processing. Color additives can be divided into two broad classes: synthetic and natural. Although the consumer's demand for use of natural food colours is growing, synthetic colours or dyes are still commonly employed by the food manufacture due to their stability at varying $\mathrm{pH}$ conditions, heat and light (Tran et al., 2020). Synthetic colours are classified as azo dyes and non azo dyes. Adverse reactions have been reported to only a few of these colorants, primarily tartrazine, also known as FD\&C Yellow 5 (Stevenson, 1992). There is an increased concern regarding consumption of synthetic colour additives amongst children due to higher consumption of candies, beverages, ice-creams etc. and associated hypersensitivities.

National Health and Nutrition Examination Survey (NHANES) conducted an exposure assessment of the approved FD\&C food 
colours through the food consumption data from 2007-2010. According to USFDA, 2011 food colours were present in about 50 food products including baby foods, biscuits, chocolates etc. Three population groups were selected namely $2+$ years or above, children between 2-5 years and teenagers of 13-18 years. The three exposure levels included were low, average and high. Exposures were estimated at the mean and $90^{\text {th }}$ percentile. It was reported that among all the FD\&C colours and all exposure values, the maximum consumption was of FD\&C Red No.40 (Allure Red), FD\&C Yellow No.5 (Tartrazine) \& FD\&C Yellow No.6 (Sunset Yellow). Further, it was concluded that there is no significant relation between the consumption of these additives and hypersensitive reactions. For population experiencing any reactions may be due to other ingredients or additives and not solely food colours (USFDA, 2011).

However, even though the studies revealed no significant effect of food colour in hypersensitive reactions, some reports were recorded with adverse reactions by synthetic as well as natural food colours.

\section{Tartrazine}

Tartrazine appears to cause the most allergic and intolerance reactions of all the azo dyes, particularly among asthmatics and those with an aspirin intolerance. Symptoms from tartrazine sensitivity can occur by either ingestion or cutaneous exposure to a substance containing tartrazine. A variety of immunologic responses have been attributed to tartrazine ingestion, including anxiety, migraines, clinical depression, blurred vision, itching, general weakness, heat waves, feeling of suffocation, purple skin patches, and sleep disturbance. Tartrazine has been shown to increase the severity of urticaria and asthma attacks especially in aspirin-intolerant patients (6-50\%). Tartrazine hypersensitivity has been noticed more in asthmatic patients (Elhkim, 2007). In a study conducted by Nettis et al., (2003) out of 102 patients who ingested tartrazine containing food, 61 experienced only urticaria, 39 experienced both urticaria and angioedema and only two suffered from only angioedema. Few individuals experienced more than one symptom like nausea, headache, nasal congestion and respiratory problems.

Several studies have been conducted on the role of tartrazine in various food sensitivity reactions, but especially in asthma and chronic urticaria. Although some studies have shown a possible causative role for tartrazine in urticaria and angioedema (Nettis E, et al., 2003), a cause and effect role for tartrazine in other illnesses has not been established (Ardern, et al., 2001). Stevenson et al., 1992 reviewed the literature on tartrazine sensitivity and concluded that tartrazine-induced asthma does not occur even among aspirin-sensitive asthmatics who were thought to be at higher risk for tartrazine sensitivity. Furthermore, routine tartrazine exclusion from the diet of asthmatics is of little value (Ardern, et al., 2001). Several methodologic flaws in earlier studies were responsible for the positive associations in these studies between tartrazine and either asthma or urticaria.

Stevenson et al., (1992) conducted the first double-blind, placebo- controlled challenge trial of tartrazine in chronic urticaria in which antihistamines were not withheld. Their patients had a history suggestive of possible tartrazine sensitivity. Only 1 of 24 patients developed urticaria on single-blind challenge, and this reaction was confirmed on doubleblind challenge. A comparatively large challenge dose of $50 \mathrm{mg}$ of tartrazine was used to provoke this response, whereas earlier studies by other investigators had used tartrazine amounts ranging from 0.1 to $25 \mathrm{mg}$. This same group has more recently indicated 
that none of 100 patients with chronic urticaria including 43 patients with histories of food and drug additive sensitivity reacted to singleblind followed by double-blind challenges with $50 \mathrm{mg}$ of tartrazine when antihistamines were continued (Rajan, et al., 2014). In summary, despite numerous reports that tartrazine can provoke chronic urticaria, convincing evidence is lacking.

The overall prevalence of tartrazine sensitivity in the population cannot be estimated from current information. Young et al., (1987) estimated the prevalence of sensitivity to tartrazine, amaranth, sunset yellow, and carmoisine to be $0 \%$ to $0.12 \%$ of their survey population of more than 18,000 , but their study procedures included the use of selfreporting of symptoms and mixed additives for challenges. However, this study would seem to indicate that the prevalence of tartrazine sensitivity is quite low.

\section{Sunset yellow}

Sunset yellow, also known as FD\&C Yellow 6 , has been linked to food sensitivities much less often than tartrazine. Sunset yellow has been implicated in several isolated cases of gastrointestinal illness confirmed by blinded challenges. Like tartrazine, sunset yellow has also been implicated in urticaria and angioedema. However, these studies had many of the same methodologic flaws previously discussed regarding tartrazine. Rajan et al., (2014) failed to identify a single reactor to sunset yellow among a total of 100 patients with chronic urticaria who were subjected to single-blind followed by double-blind, placebo- controlled challenges under conditions in which antihistamines were not withheld. Worm, et al., (2000), evaluated the role of a group of food additives in provoking atopic dermatitis, 6 of 15 patients experienced worsening of their atopic dermatitis on double-blind challenge with an additive mixture, but sunset yellow was only 1 of 22 common food additives included in the challenge trial (Worm, 2000). Sunset yellow has also been implicated in asthma, but challenge studies conducted with 45 aspirinsensitive asthmatic patients failed to identify any subjects who were reactive to sunset yellow (Weber et al., 1979). Sunset yellow has been implicated in one case of purpura (Michaelson et al., 1974) and two cases of orofacial granulomatosis (Pachor et al., 1989; Sweatman, et al., 1986). As noted earlier, the prevalence of sunset yellow sensitivity in the population appears to be very low (Young et al., 1987).

In another study, 56 patients suffering from urticaria and angioneurotic oedema were provoked to sunset yellow and in $17 \%$ of them, the symptoms of urticaria angioneurotic oedema increased. They got reactions within 4 hours of intake of this additive (Gultekin, 2013). In a 8 year old child suffering from orofacial granulomatosis, the cause of this was found to be exposure to few food additives including sunset yellow (Gultekin et al., 2013).

\section{Other synthetic colors}

Several other synthetic food colors have occasionally been implicated in urticaria, angioedema, asthma, and atopic dermatitis. These synthetic colors include amaranth (FD\&C Red No.2), erythrosine (FD\&C Red No.3), brilliant blue (FD\&C Blue No.1), ponceau $4 \mathrm{R}$, carmoisine, quinoline yellow, patent blue, azorubin, new coccine, indigo carmine (FD\&C Blue No.2), brilliant black $\mathrm{BN}$, and fast green (FD\&C Green No.3). Studies of these food and drug colors have had the same methodologic flaws previously discussed for tartrazine. Thus, there is no compelling evidence for the involvement of these colors in urticaria, angioedema, asthma, or atopic dermatitis. Isolated cases of asthma 
have been linked to ponceau and erythrosine (Weber, et al., 1979). New coccine has been implicated in a single case of purpura (Michaelsson, et al., 1974). A single case of leukocytoclastic vasculitis has been ascribed to ponceau red $4 \mathrm{R}$ and confirmed by a placebo-controlled oral challenge with $50 \mathrm{mg}$ of the dye (Veien et al., 1991). Pacor et al., 2004, implicated erythrosine as a possible factor in persistent rhinitis in 7 of 226 patients who were evaluated. Sweatman, et al., 1986 reported a case of orofacial granulomatosis linked to ingestion of carmoisine. Young et al., estimated that the prevalence of sensitivities to green $\mathrm{S}$, quinoline yellow, and indigo carmine is $0 \%$ to $0.11 \%$.

\section{Natural food colorants}

Natural colorants that are used in foods include annatto, caramel, carmine, carotene, turmeric, paprika, beet extract, and grape skin extract. These types of colorants are not used to any extent in pharmaceutical applications. Several studies have reported positive reactions after challenges with mixtures of natural colors or mixtures of natural and synthetic colors (Lucas, 2001; Fuglsang, 1994). The natural colorants involved in these challenges were annatto, betanin, curcumin, turmeric, $\beta$-carotene, canthaxanthin, and beet extract. The adverse reactions were asthma, urticaria, atopic dermatitis, colic, and vomiting. No one color can be identified as the causative factor when challenges are conducted with mixtures.

\section{Annatto}

Annatto is obtained as an extract from the seeds of the fruit of the Central and South American tree, Bixa orellana. Bixin, the principal pigment in annatto, is a carotenoid. Although the extracts are red in color, annatto is often used to impart an orange or deepyellow color to the finished food. It is commonly used as a colourant in ice-creams, butter, cheeses, and bakery products. Study conducted by Gultekin and Dogue (2013) have shown annatto to be responsible for hypersensitive reactions and intensifies the symptoms of urticaria. Similarly, Myles, et al., 2009 have noted patient reactions to crackers in many case reports of probable IgE-mediated sensitivity to annatto. Ebo, et al., (2009); Ramsey, et al., (2016) reported in cheese and Nish et al., 1991 reported in breakfast cereal. Clinical reactions to annatto have been confirmed by positive prick skin tests, basophil activation, and IgE-binding (Ebo, 2009; Nish et al., 1991). An IgE-binding protein was identified through sodium dodecyl sulfite-polyacrylamide gel electrophoresis (SDS-PAGE) and immunoblotting (Nish et al., 1991). This is not surprising, because annatto is derived from a seed extract. Young et al., estimated that the prevalence of annatto sensitivity is $0.01 \%$ to $0.07 \%$.

\section{Carmine red}

Carmine and cochineal extract are derived from dried female cochineal insects, Dactylopius coccus Costa, which live as a parasite on the prickly pear cactus. An aqueous-alcoholic extract of the dried insects is made and concentrated, by removal of the alcohol, to obtain the color additive, cochineal extract. The principal coloring agent is carminic acid. Carmine is the aluminum or calcium-aluminum lake of the coloring principals, primarily carminic acid, obtained by aqueous extraction of cochineal. Carmine and cochineal extract have a red color.

Carmine is widely used in cosmetics, but only a few cases of dermatologic reactions have been attributed to it. According to Park, et al., 1981 a case of severe anaphylactic shock possibly resulted from the cutaneous use of carmine. Unfortunately, no follow-up was done on this patient to confirm the role of 
carmine in this case. Shaw, 2009 have reported a few cases of contact dermatitis to carmine. Cases of urticaria and angioedema with positive prick skin tests and serum specific-IgE to carmine have been described in the literature (Greenhawt et al., 2009; Yamakawa et al., 2009). Five cases of anaphylaxis were associated with ingestion of campari with positive skin tests and specific IgE (Wuthrich et al., 1997). Diagnosis of carmine hypersensitivity can be difficult because of the nature of the protein residues and interactions with carminic acid. Oral challenges may be necessary to confirm carmine hypersensitivity (Liippo et al., 2015). Cases of occupational asthma have been reported as well (Anibarro, et al., 2003; TabarPurroy et al., 2003).

Lemoine, A., et al., (2020) observed in a test that a patient developed localised urticaria 60 minutes after ingestion of food containing carmine red. Because carmine is an extract obtained from insect bodies, it contains proteins capable of eliciting IgE-mediated reactions. Chung $\mathrm{K}$ et al., 2001 identified several IgE-binding proteins, and a major 38$\mathrm{kD}$ cochineal allergen has been molecularly cloned and has sequence homology to phospholipases. (Ohgiya et al., 2009)

\section{Indigo carmine}

It is considered a safe dye to be used in food stuffs by FSSAI. It is used in several confectionary items, ice creams etc. However, some isolated cases of reactions to indigo carmine has been reported. It was observed that when a woman was given Synthroid tablets (blue in colour) she experienced severe urticaria all over the body. Further studies revealed the cause of this reaction to be the indigo carmine used in the tablets. Substitution of these tablets with dye free tablets, didn't show any reoccurrence of urticaria (Magner et al., 1994).

\section{Flavoring agents}

Numerous flavoring substances are used in foods products. Many flavoring formulations contain hundreds of different chemical compounds. On food-ingredient labels, natural and artificial flavors typically appear as the final ingredient on the list of ingredients, because flavors are the least prevalent components of the formulated product.

A few reports exist of IgE-mediated allergic reactions to flavoring ingredients in circumstances where the flavor formulations contain allergenic proteins (Taylor \& Taylor et al., 1998). Flavorings that contain allergenic proteins are rare. Traces of milk protein were found in hot dogs and bologna incriminated in reactions involving four milk-allergic patients (Gern, 1991). The milk protein came from use of a hydrolyzed sodium caseinate ingredient as a flavor enhancer in the cured meats. St Vicent et al., 1994 reported of dill pickle seasoning on a potato chip as an unexpected source of milk protein that caused reactions in two patients. McKenna et al., 1997, reported of a severe, life-threatening systemic allergic reaction from ingestion of a soup mix that contained peanut flour as a component of the natural flavoring. According to Taylor et al., 1998 though the only examples in the literature involve milk and peanuts, the possibility exists that similar reactions can occur to soybeans, eggs, seafood, and other allergenic materials used occasionally in the formulation of certain flavorings. He proposed the level of allergen resulting from flavors would be extremely low and likely insufficient to provoke allergic reactions in every case.

On rare occasions, flavoring substances can cause contact sensitization in the oral cavity. According to Taylor et al., 1998 most of these episodes involve products that are in prolonged contact with the oral cavity, such as chewing gum, toothpaste, hard candies etc. 
Scheman et al., 2013 reported of balsam of Peru typically causes contact reactions including dermatitis and urticaria. These reactions most often occur from the use of balsam of Peru in cosmetics, especially fragrances, but can occur from contact in the oral cavity through foods, chewing gum, and toothpaste (Taylor et al., 1998). Similarly, according to Taylor et al., several other flavoring substances, including anethole, anise oil, cinnamon and cinnamic compounds, eugenol, menthol, peppermint oil, and spearmint oil, are known to cause similar reactions occasionally. Rarely, systemic reactions to flavoring agents are reported. Paiva et al., 2009 reported of anaphylaxis from mint (menthe) in toothpaste occurred in a patient who had a positive prick skin test to peppermint oil. An isolated case of angioedema and gastrointestinal distress from fragrances containing cinnamic derivatives used as flavoring in foods was confirmed by DBPC challenge (Ricciardi et al., 2007). These substances rarely cause reactions unless they are used in products that have prolonged contact with the oral cavity and are present in relatively high concentrations.

\section{Monosodium Glutamate (MSG)}

MSG is a popular flavor enhancer which occurs naturally but is also added to many foods. MSG is the sodium salt of one of the most common amino acids in the human body and is present in Chinese foods. Though MSG has been given the GRAS status (Generally Regarded as Safe), it still has some controversial reports. It is known to cause headaches, numbness, fluttering heartbeats, nausea and even brain damage in extreme cases. MSG was reported as "Chinese restaurant Syndrome" in 1968 as a series of reactions (palpitation, weakness and numbness) occurred after consumption of Chinese food (Gultekin, et al., 2013). In general, no clear, consistent relationship exists between MSG ingestion and the development of asthma. FDA on further investigation by Federation of American Societies for Experimental Biology (FASEB), regarded MSG as safe though some short-term effects like headache, numbness, flushing, tingling, palpitations, and drowsiness were identified in some sensitive individuals who consume $3 \mathrm{~g}$ or more of MSG. But this is unlikely to happen as foods having MSG, do not contain more than $0.5 \mathrm{~g}$ of it (USFDA, 2012).

\section{Emulsifier and stabilizers}

\section{Lecithin}

Lecithin is as naturally occurring mixture of phosphatides. Lecithin is used as an emulsifier in food applications. The primary source of lecithin is soybeans; other sources include eggs, rice, sunflower seeds, and rapeseed. Although primarily phospholipids, soy lecithin contains soy protein and soy allergen residues (Gu et al., 2001; Paschke et al., 2001) Despite its widespread use as a food ingredient, allergic reactions to soy lecithin have been described on only a few occasions (Palm et al., 1999; Renaud et al., 1996). Lecithin contains rather low levels of residual protein. Soy lecithin contains between 230 and 1300 $\mathrm{mg} / \mathrm{kg}$ of soy protein.

Baker's asthma is a disease commonly seen among the workers of a baking industry. Lavaud, et al., 1994 reported the occurrence of rhinitis along with asthma and cough with sputum, in a baker.

His wheezing improved considerable on quitting work. It was observed that soy lecithin was used in baking. Similarly, a child reported of abdominal pain and diarrhoea. Positive results on skin prick test were seen for soy lecithin. On restriction of soy-lecithin from his diet, his symptoms improved (Catherine et al., 1996). 


\section{Gums}

Many different types of gums are used in foods. The major gums are guar, tragacanth, xanthan, carrageenan, acacia (gum Arabic), locust bean, and alginate. Several of these gums are legumes, including guar, tragacanth, locust bean, and acacia; some other members of the legume family such as peanut are intensely allergenic. However, allergic reactions from the ingestion of gums are infrequent. The gums are primarily composed of complex polysaccharides but occasionally contain residues of proteins.

\section{Guar Gum}

Guar gum is a plant seed gum generally used in food industry as a binding agent and as colour fixing agent. Cases related to guar gum sensitivity have been reported. Papanikolaou et al., 2007 reported a case of anaphylaxis resulting from the ingestion of guar gum in several foods and beverages. Anaphylactic shock was attributed to ingestion of guar gum complicated by coincident ingestion of aspirin (Infante et al., 2014) Positive basophil activation was reported, although the presence of specific IgE to guar gum could not be demonstrated. Bridts et al., 2002 reported use of guar gum as a gelling agent for a local anesthetic in a dental procedure elicited severe contact urticaria upon application to the oral mucosa.

Roesch et al., 2005; Danoff et al., 1997 reported several cases each of allergic reactions to gum tragacanth and James et al., 2017 reported of gum Arabic (acacia gum). Tarlo et al., 1995 has implicated carrageenan gum in a case of anaphylaxis resulting from its use in a barium enema) Allergic sensitization to carob bean gum was confirmed by challenge in an infant (Savino et al., 1999). Papanikolaou, et al., 2007 reported of severe anaphylactic reactions after few minutes of consumption of a meal containing guar gum. Tests for acetylsalicylic acid and few food additives were conducted. All came negative except for guar gum. The symptoms subsided after discontinuing guar gum containing products.

\section{Locust bean gum}

Locust bean is also a plant seed gum used in food industry as a stabilizer, thickening \& gelling agent in jams, jelly, infant formulas etc. Severe reactions to this gum have been reported. Adverse reactions on consumption of cow's milk formula (CMF) containing locust bean gum like vomiting, watery diarrhoea, non-responsiveness, drowsiness etc was reported. On replacing the cow's milk formula with a casein based extensively hydrolysed formula (EHF), the child recovered (Jędrzejczyk, et al., 2020).

\section{Preservatives}

\section{Sulfites}

Sulphites or sulfiting agents are commonly used as preservatives, anti-browning agent and as antioxidant in various food products. Although they are safe for human consumption, however some serious allergic reactions have been reported. A high correlation is found between the ISAAC (International Study of Asthma \& Allergies in Childhood) study and the average food additive intake. According to WHO, 4\% of asthmatic population was updated to $20-30 \%$ of the asthmatic children who were sensitive to sulphites. (Dengate and Dengate, 2004)

Sulfites or sulfiting agents used as food additives include sulfur dioxide $\left(\mathrm{SO}_{2}\right)$, sodium and potassium metabisulfite $\left(\mathrm{Na}_{2} \mathrm{~S}_{2} \mathrm{O}_{5}\right.$, $\mathrm{K}_{2} \mathrm{~S}_{2} \mathrm{O}_{5}$ ), sodium and potassium bisulfite $\left(\mathrm{NaHSO}_{3}, \mathrm{KHSO}_{3}\right)$, and sodium sulfite $\left(\mathrm{Na}_{2} \mathrm{SO}_{3}\right)$, but they can also occur naturally in 
many foods, particularly fermented beverages such as wines (Taylor et al., 1996).

Sulfites are added to many different types of foods for several technical purposes (Table 2). Because sulfites have a wide variety of applications as food additives, a wide range of residual sulfite concentrations can be found in foods (Table 3). The more highly sulfited foods such as dried fruits, potato products, wine etc. pose greater hazard to sulfitesensitive individuals. Sulfites are extremely reactive in food systems. A dynamic equilibrium exists between free sulfites and many bound forms of sulfites. The fate of sulfites added to foods is variable and depends on the nature of each individual food (Bush et al., 1996). At an acidic pH (less than 4.0), sulfur dioxide can be released as a gas from food or solutions containing sulfites.

Sulfites react with a variety of food constituents (Taylor et al., 1996). Some of these reactions are readily reversible, whereas others are virtually irreversible. Adverse reactions suggestive of a hypersensitivity response have been observed, including allergic contact dermatitis confirmed by patch testing (Madan et al., 2002, Harrison et al., 2002, Ralph N et al., 2015). Sodium metabisulfite appears to be the most common cause of these reactions. Ralph reported several cases of angioedema and urticaria (Belchi-Hernandez et al., 1993, Wuthrich et al., 1992, V et al., 1993). In contrast, Simon, using a rigorous blinded, placebo- controlled trial with objective criteria for positive reactions, was unable to demonstrate positive reactions to encapsulated metabisulfite (200 mg maximum dose) in 75 patients with chronic urticaria, anaphylaxis, or both and a history suggestive of sulfite sensitivity. Whereas some individuals may develop urticaria or anaphylactoid reactions as adverse reactions to sulfites, the frequency with which these reactions occur, at best, is extremely rare and requires confirmation by rigorous doubleblinded challenges.

Challenge studies with sulfited foods have been conducted in sulfite- sensitive patients with asthma. Clinical challenges with acidic solutions of sulfite in lemon juice or other vehicles demonstrate these to be more hazardous than other forms of sulfited foods.(Simon, 1998) Furthermore, it has been conclusively demonstrated that sulfited lettuce (banned FDA regulations) can trigger asthmatic reactions in sulfite- sensitive individuals (Taylor et al., 1988). Foods where sulfites exist primarily in the bound form, such as shrimp, are less likely to induce responses.

Certainly, all sulfite-sensitive asthmatic patients should be instructed to avoid the more highly sulfited foods with an excess of 100 ppm of $\mathrm{SO}_{2}$ equivalents (Table 3). Strict avoidance and eliminating of all sulphite containing foods in the diets of individuals with lower thresholds is the only remedy to prevent hypersensitivity in susceptible individuals.

Packaged foods containing more than $10 \mathrm{ppm}$ residual $\mathrm{SO}_{2}$ equivalents must have the presence of sulfites written on the label. Sulfite- sensitive consumers need to be aware that the terms sulfur dioxide, sodium or potassium bisulfite, sodium or potassium metabisulfite, and sodium sulfite are all sulfites or sulfiting agents.

Whereas avoidance of prepared and packaged foods is relatively straightforward, avoidance of sulfites in restaurant foods is more difficult.

Some unlabeled sulfite containing foods remain in restaurants despite the FDA ban on their use on fresh fruits and vegetables. The major contributing problem is sulfited potatoes. Therefore, sulfite-sensitive individuals should be instructed to avoid all 
potato products in restaurants except baked potatoes with skins intact.

\section{Benzoic acid and benzoates}

Sodium benzoate, benzoic acid, and various esters of para hydroxybenzoic acid (parabens) are widely used antimicrobial preservatives in foods, drugs, and cosmetics. pHydroxybenzoic acid is also known as salicylic acid, which is structurally related to aspirin, a well-known cause of sensitivity disorders. The possible role of benzoates and parabens in chronic urticaria and angioedema has been investigated, but many of these studies are plagued by design flaws. In a study of 100 patients with chronic urticaria with and without histories of food additive sensitivity using both single-blind and DBPC challenges, neither sodium benzoate (100 mg) nor methyl paraben $(100 \mathrm{mg})$ provoked urticarial flares (Rajan, 2014).

In less well-controlled studies, benzoate has been implicated in chronic urticaria.(Reus, 2000) For the parabens, according to Reus the data are insufficient to adequately judge whether any allergic reactions can be attributed to their oral use. Contact dermatitis is a well-recognized reaction to parabens in sunscreens, eye drops, and shampoos from cutaneous application (Fahrenholz et al., 2008, Yim et al., 2014, Warsaw et al., 2015, Jimenez-Arnau et al., 2017).

Benzoate and p-hydroxybenzoate have also been associated with persistent rhinitis. Asero, 2001 in a single case of perennial rhinitis induced by sodium benzoate confirmed on repeated, double-blind challenge.

Challenges with up to $200 \mathrm{mg}$ of benzoate or p-hydroxybenzoate elicited both objective and subjective symptoms of rhinitis together with $20 \%$ or greater reduction of nasal peak inspiratory flow rate in 19 of 20 who reported improvement on the additive-free diet (Pacor, 2004).

According to Fahrenholz et al., 2008 rarely, sodium benzoate has been implicated in cases of cutaneous vasculitis. And Sodium benzoate is not a known cause of systemic anaphylaxis or anaphylactoid reactions. Although the estimated prevalence of reactions to sodium benzoate was $0.01 \%$ to $0.11 \%$, Young and coworkers conducted challenges with mixtures of aspirin and benzoate. Because aspirin is a well-established sensitizing substance, most of their reactions could have been caused by aspirin, not benzoate.

\section{Sorbate/sorbic acid}

Sorbic acid and its potassium salt are widely used antimicrobial preservatives in foods, especially for preventing mold growth on food products. Sorbates have been infrequently implicated in adverse reactions, especially by the oral route. Many of the studies on sorbate have the same methodologic flaws. Volonakis and co-workers reported that among 226 patients with chronic urticaria who were challenged with 50 to $200 \mathrm{mg}$ of sorbic acid, none had responses. However, in a smaller study, Ehlers et al., reported of two out of six patients with chronic urticaria responded to DBPC challenge with a higher dose of 1000 mg sorbic acid. In a study evaluating a group of food additives in the provocation of atopic dermatitis, 6 of 15 patients experienced worsening of their atopic dermatitis on double-blind challenge with an additive mixture, but sorbic acid was only 1 of 22 common food additives included in the challenge trial (Worm, 2000). Clemmensen et al., reported of sorbic acid caused contact urticaria in the perioral region, especially in children who smear sorbate-containing foods around their face. Rarely, sorbic acid has caused contact dermatitis (Golightly et al., 1988). 
Table.1 Key studies on prevalence of hypersensitivity to food additives

\begin{tabular}{|c|c|c|c|c|}
\hline Country & $\begin{array}{c}\text { Prevalence in } \\
\text { percentage }\end{array}$ & $\begin{array}{c}\text { Number of } \\
\text { subjects }\end{array}$ & Type of study & Reference \\
\hline UK & 0.026 & 11,000 & $\begin{array}{c}\text { Questionnaires followed by oral } \\
\text { challenge using additives most } \\
\text { commonly reported to cause } \\
\text { adverse reaction. }\end{array}$ & $\begin{array}{c}\text { Young } \text { et al. } \\
1987\end{array}$ \\
\hline Denmark & $1-2$ & 4274 & $\begin{array}{c}\text { Questionnaire followed by oral } \\
\text { challenge. }\end{array}$ & $\begin{array}{c}\text { Fuglsang } \text { et al. } \\
1993\end{array}$ \\
\hline Germany & 2.6 & 13,300 & $\begin{array}{c}\text { Questionnaire collection and skin } \\
\text { prick test }\end{array}$ & $\begin{array}{c}\text { Zuberbier } \text { et al. } \\
\text { ald }\end{array}$ \\
\hline Netherlands & 2.4 & 1483 & $\begin{array}{c}\text { Questionnaire and clinical follow } \\
\text { up confirmed by double-blind } \\
\text { placebo-controlled food challenge. }\end{array}$ & $\begin{array}{c}\text { Jansen } \text { et al. } \\
\text { (1994) }\end{array}$ \\
\hline
\end{tabular}

Table.2 Technical attributes of sulfites in foods

\begin{tabular}{|c|c|}
\hline Examples of Specific Food Technical Attribute & Applications \\
\hline Inhibition of enzymatic browning & $\begin{array}{l}\text { Fresh fruits and vegetables, Salads }{ }^{\mathrm{a}} \\
\text { Guacamole }^{\mathrm{a}} \text {, Shrimp (black spot formation) Pre- } \\
\text { peeled raw potatoes }\end{array}$ \\
\hline Inhibition of non-enzymatic browning & $\begin{array}{l}\text { Dehydrated potatoes Other dehydrated vegetables, } \\
\text { Dried fruits }\end{array}$ \\
\hline Antimicrobial actions & $\begin{array}{l}\text { Wines, Corn wet milling to make cornstarch, corn } \\
\text { syrup }\end{array}$ \\
\hline Dough conditioning & Frozen pie crust Frozen pizza crust \\
\hline Antioxidant action & No major US applications \\
\hline Bleaching effect & Maraschino cherries Hominy \\
\hline
\end{tabular}

${ }^{a}$ No longer allowed by US Food and Drug Administration.

Source: From Taylor SL, Bush RK, Nordlee JA. Sulfites. In: Metcalfe DD, Sampson HA, Simon RA, editors: Food allergy. Adverse reactions to foods and food additives. Boston: Blackwell Scientific; 1996. p 348.

Table.3 Estimated total $\mathrm{SO}_{2}$ level as consumed for some sulfited foods

\begin{tabular}{|c|c|}
\hline$>100 \mathrm{ppm}$ & $\begin{array}{c}\text { Dried fruit (excluding dark raisins and } \\
\text { prunes), Lemon juice (nonfrozen), Lime juice (nonfrozen),Wine, } \\
\text { Molasses, Sauerkraut juice } \\
\text { Grape juice (white, white sparkling, pink sparkling, red sparkling), } \\
\text { Pickled cocktail onions. }\end{array}$ \\
\hline 50 to 99.9 ppm & $\begin{array}{l}\text { Dried potatoes, Wine vinegar, Gravies, sauces } \\
\text { Fruit topping, Maraschino cherries. }\end{array}$ \\
\hline 10.1 to $49.9 \mathrm{ppm}$ & $\begin{array}{c}\text { Pectin, Shrimp (fresh), Corn syrup } \\
\text { Sauerkraut, Pickled peppers, Corn starch } \\
\text { Hominy, Frozen potatoes, Maple syrup, Imported jams and jellies, Fresh } \\
\text { mushrooms. }\end{array}$ \\
\hline$<10 \mathrm{ppm}$ & $\begin{array}{c}\text { Malt vinegar, Canned potatoes, Beer, Dry soup mix, Soft drinks, Instant } \\
\text { tea, Pizza dough (frozen), Pie dough, Sugar (especially beet sugar), } \\
\text { Gelatin, Coconut, Fresh fruit salad, Domestic jams and jellies, Crackers, } \\
\text { Cookies, Grapes, High fructose corn syrup. }\end{array}$ \\
\hline
\end{tabular}

Source: Taylor SL, Bush RK, Nordlee JA. Sulfites. 
Table.4 List of food additives with their uses and hypersensitivities as reported in literature

\begin{tabular}{|c|c|c|c|c|}
\hline $\begin{array}{c}\text { Category of } \\
\text { Food Additives }\end{array}$ & $\begin{array}{c}\mathbf{E} \\
\text { Number }\end{array}$ & Food uses & Adverse effects & References \\
\hline $\begin{array}{l}\text { Antioxidants } \\
\text { BHA and BHT }\end{array}$ & $\begin{array}{c}\text { E } 320 \& \& \\
321\end{array}$ & $\begin{array}{l}\text { Cereal-based snack foods, } \\
\text { dehydrated meat, seasonings and } \\
\text { condiments, fats and oils, cake } \\
\text { mixes. } \\
\text { Fats and oils rich foods, bakery } \\
\text { products. }\end{array}$ & $\begin{array}{l}\text { Atopic dermatitis, urticarial, } \\
\text { rhinitis, asthma, headache. } \\
\text { Dermatitis, angioedema, } \\
\text { inflammation }\end{array}$ & $\begin{array}{l}\text { (Worm et al. 2010; } \\
\text { Metcalfe } \text { et al. 2008; } \\
\text { Allen } \text { et al. } 1987 \text { ) } \\
\\
\text { (Kahn et al. 1974; } \\
\text { Gultekin } \text { et al. 2013; } \\
\text { Melgares } \text { et al. 2007). }\end{array}$ \\
\hline $\begin{array}{l}\text { Sunset yellow } \\
\text { Annato } \\
\text { Carmine red }\end{array}$ & $\begin{array}{l}\text { E } 110 \\
\text { E160 }\end{array}$ & $\begin{array}{l}\text { Cheese, canned or bottled fruit or } \\
\text { vegetables, fishery products, } \\
\text { pickles, seasonings, non-alcoholic } \\
\text { flavoured drinks. } \\
\text { Cheese, breakfast cereals, } \\
\text { processed fish products, jams, } \\
\text { processed potato products, meat } \\
\text { products, noodles. } \\
\text { Candy, ice cream, snacks, juices, } \\
\text { meat products. }\end{array}$ & $\begin{array}{l}\text { Urticaria, angioedema, atopic } \\
\text { eczema, atopic dermatitis, drug } \\
\text { eruption, anaphylaxis, nausea. } \\
\text { Urticaria, angiooedema, } \\
\text { anaphylaxis, asthma, irritable } \\
\text { bowel syndrome. } \\
\text { Urticaria, anaphylaxis, irritable } \\
\text { bowel syndrome. }\end{array}$ & $\begin{array}{c}\text { (Iberro et al. 1982; } \\
\text { Mikkelsen } \text { et al. 1978; } \\
\text { Pestana et al. 2010; } \\
\text { Devlin and David } \\
\text { 1992; Inomata } \text { et al. } \\
\text { 2006) } \\
\text { (Worm et al. 2000; } \\
\text { Weber } \text { et al 1979) } \\
\text { (Gultekin and Dogue } \\
\text { 2013; Myles et al } \\
\text { 1999) }\end{array}$ \\
\hline Indigo Carmine & E120 & $\begin{array}{l}\text { Cheese, jams, chewing gums, } \\
\text { breakfast cereals, meat products, } \\
\text { soups, sauces, dietary products, } \\
\text { desserts, beverages. } \\
\text { Ice cream, confectionary } \\
\text { products. }\end{array}$ & $\begin{array}{l}\text { Rhinoconjunctivitis, urticaria, } \\
\text { asthma, } \\
\text { anaphylaxis, angioedema. } \\
\text { Severe anaphylaxis and urticarial. }\end{array}$ & $\begin{array}{l}\text { (Park et al. 1981; } \\
\text { Shaw 2009; Greenhawt } \\
\quad \text { et al. 2009). } \\
\\
\text { (Magner } \text { et al. 1994) }\end{array}$ \\
\hline $\begin{array}{l}\text { Flavoring agents } \\
\text { Monosodium } \\
\text { glutamate }\end{array}$ & E621 & $\begin{array}{l}\text { Processed cheese, breakfast } \\
\text { cereals, noodles, bread and rolls, } \\
\text { processed fish and fishery } \\
\text { products, processed eggs and egg } \\
\text { products, seasonings and } \\
\text { condiments, soups, sauces, } \\
\text { dietary foods, meat products. }\end{array}$ & $\begin{array}{l}\text { Headache, numbness, nausea, } \\
\text { urticaria, asthmatic reactions, } \\
\text { angiooedema, rhinitis }\end{array}$ & $\begin{array}{l}\text { (Gultekin et al. 2013; } \\
\text { Supramaniam et al. } \\
\text { 1986; Allen et al. } \\
\text { 1987). }\end{array}$ \\
\hline $\begin{array}{l}\text { Emulsifiers \& } \\
\text { Stabiliers } \\
\text { Lecithin }\end{array}$ & E 322 & $\begin{array}{l}\text { Confectionery, chocolate, fat } \\
\text { spreads, bakery products. }\end{array}$ & $\begin{array}{c}\text { Rhinitis, asthma, abdominal pain, } \\
\text { diarrhoea. }\end{array}$ & $\begin{array}{l}\text { (Lavaud et al. 1994; } \\
\text { Catherine et al. 1996) }\end{array}$ \\
\hline Guar gum & E 412 & $\begin{array}{l}\text { Bakery products, dairy products, } \\
\text { meat, soups. }\end{array}$ & Anaphylaxis, urticarial. & $\begin{array}{l}\text { (Papanikolaou et al. } \\
\text { 2007; Infante } \text { et al. } \\
\text { 2014; Bridts } \text { et al. }\end{array}$ \\
\hline
\end{tabular}




\begin{tabular}{|c|c|c|c|c|}
\hline $\begin{array}{l}\text { Locust bean } \\
\text { gum }\end{array}$ & E 410 & Ice cream, desserts, jams, jellies. & $\begin{array}{l}\text { Gastrointestinal distress, } \\
\text { vomiting, drowsiness. }\end{array}$ & $\begin{array}{l}\text { 2002). } \\
\text { (Jedrzejczyk et al. } \\
\text { 2020) }\end{array}$ \\
\hline $\begin{array}{l}\text { Preservatives } \\
\text { Sulfites }\end{array}$ & $\begin{array}{l}\text { E 220- } \\
229\end{array}$ & $\begin{array}{l}\text { Fresh and processed fruits and } \\
\text { vegetables, cereals, starches, meat } \\
\text { preparations (sausages), } \\
\text { processed fish and fishery } \\
\text { products, alcoholic and non- } \\
\text { alcoholic beverages. }\end{array}$ & $\begin{array}{l}\text { Contact dermatitis, urticaria, } \\
\text { anaphylaxis, angioedema, } \\
\text { asthmatic reactions in asthmatic } \\
\text { individuals. }\end{array}$ & $\begin{array}{l}\text { (Dengate and Dengate } \\
\text { 2004; Madan } \text { et al. } \\
\text { 2002; Ralph } \text { et al. } \\
\text { 2015; Belchi } \text { et al. } \\
\text { 1993) }\end{array}$ \\
\hline Benzoates & $\begin{array}{c}\text { E 210- } \\
219\end{array}$ & $\begin{array}{l}\text { Acidic foods such as salad } \\
\text { dressings, carbonated drinks, } \\
\text { jams, pickles and fruit juices. }\end{array}$ & $\begin{array}{l}\text { Contact dermatitis, urticaria, } \\
\text { persistent rhinitis, angioedema. }\end{array}$ & $\begin{array}{l}\text { (Reus 2000; Jiminez et } \\
\text { al. 2017; Asero 2001) }\end{array}$ \\
\hline Sorbates & $\begin{array}{l}\text { E 200- } \\
209\end{array}$ & $\begin{array}{l}\text { Cheese, wine, dried meat } \\
\text { products, bakery products. }\end{array}$ & $\begin{array}{l}\text { Contact urticarial, atopic } \\
\text { dermatitis. }\end{array}$ & $\begin{array}{c}\text { (Worm 2000; Ehlers et } \\
\text { al 1998) }\end{array}$ \\
\hline Nitrates & $\begin{array}{c}\text { E } 240- \\
259\end{array}$ & Meat products & Chronic urticarial, anaphylaxis. & $\begin{array}{l}\text { (Moneret et al 1980; } \\
\text { Hawkins et al 2000) }\end{array}$ \\
\hline $\begin{array}{l}\text { Sweeteners } \\
\text { Aspartame }\end{array}$ & E 951 & $\begin{array}{l}\text { Jam, chewing gum, breakfast } \\
\text { cereals, processed fish and fishery } \\
\text { products, soups, sauces, dietary } \\
\text { foods, beer and malt beverages, } \\
\text { soft drink, diet soda, snacks. }\end{array}$ & $\begin{array}{l}\text { Systemic Contact Dermatitis, } \\
\text { Chronic headache, early } \\
\text { menarche. }\end{array}$ & $\begin{array}{l}\text { (Matiz et al 2011; } \\
\text { Lipton } \text { et al. 1989; } \\
\text { Mueller } \text { et al 2015) }\end{array}$ \\
\hline $\begin{array}{l}\text { Acesulfame } \\
\text { Potassium }\end{array}$ & E 950 & Carbonated drinks & Hives and throat discomfort. & \\
\hline Mannitol & E 421 & $\begin{array}{l}\text { Candies, dried foods, chewing } \\
\text { gums. }\end{array}$ & Angiodema, urticaria, & $\begin{array}{l}\text { (Calogiuri et al. 2013; } \\
\quad \text { Jain et al. 2015) }\end{array}$ \\
\hline \multirow[t]{2}{*}{$\begin{array}{l}\text { Erythritol } \\
\text { Maltitol }\end{array}$} & $\begin{array}{l}\text { E } 968 \\
\text { E } 965\end{array}$ & $\begin{array}{l}\text { Beverages, confectionery and } \\
\text { bakery products. }\end{array}$ & $\begin{array}{l}\text { anaphylactic shock. } \\
\text { Urticaria and anaphylaxis. }\end{array}$ & $\begin{array}{c}\text { (Hino et al. 2000; } \\
\text { Shirao et al 2013) } \\
\text { (Trabado et al. 2017) }\end{array}$ \\
\hline & & $\begin{array}{l}\text { Candy, chewing gum, chocolates } \\
\text { and ice cream. }\end{array}$ & $\begin{array}{l}\text { Dyspnea, facial flushing, and } \\
\text { pharyngeal occlusion }\end{array}$ & \\
\hline
\end{tabular}

\section{Nitrate and nitrite}

Sodium nitrate and sodium nitrite are used as curing agents in meat products. Few reactions have been attributed to nitrate or nitrite, and most reports are compromised by methodologic flaws. Limited evidence exists for a role for nitrate and nitrite in provocation of chronic urticaria. Volonakis along with coworkers conducted challenges of 226 patients with $100 \mathrm{mg}$ each of nitrate and nitrite and revealed no reactors, and similarly, Ranjan and et al., conducted challenges of 100 patients with $50 \mathrm{mg}$ each showed no reactors. However, Moneret-Vautrin et al., (1980) found that four patients with chronic urticaria 
had symptoms provoked in DBPC challenges by sodium nitrite. A 22-year-old man had anaphylaxis confirmed by DBPC challenge with nitrates and nitrites (Hawkins et al., 2000). A patient had chronic generalized pruritus confirmed by DBPC challenge with a 10-mg dose of sodium nitrate, but no repeat challenge was performed (Asero, 1999). Further studies are needed to confirm the role of nitrates and nitrites in such generalized reactions.

\section{Sweeteners}

\section{Aspartame}

Aspartame is a nonnutritive sweetener extensively used in food and beverage applications. Numerous anecdotal reports of adverse reactions to aspartame have included headaches and various neuropsychiatric symptoms, including seizures (Garriga et al., 1998). However, no clear symptom complex ever emerged from these complaints. Furthermore, careful evaluation of individuals with self-reported aspartame sensitivity through single-blind and double-blind challenges failed to identify a single aspartame reactor out of 61 individuals evaluated (Garriga et al., 1991). In a randomized DBPC crossover study, aspartame was no more likely than placebo to elicit urticaria or angioedema (Geha et al., 1993). Similarly, Both Rajan, 2014 and Simon, 2000 found no role of aspartame in the provocation of chronic urticaria in DBPC challenges of patients with or without histories of sensitivities to food additives.

\section{Acesulfame potassium}

Like aspartame, acesulfame potassium, also known as acesulfame $K$, is a nonnutritive sweetener. Only one case report of a possible adverse reaction to acesulfame potassium exists, (Stohs et al.,2013) but that report was based upon a dietary history and not confirmed by challenge.

\section{Mannitol}

Mannitol is a sugar alcohol that has many applications in special dietetic foods as a food additive. Calogiuri et al., 2013 reported that Mannitol has been associated with acute onset of urticaria and angioedema in a patient taking paracetamol orally. Similarly, Hegde and coworkers, 2004 also reported that Mannitol provoked reactions upon exposure as a chewable pharmaceutical. Cases of severe anaphylactic shock have rarely occurred when mannitol was administered intravenously (Jain et al., 2015, Yunginger et al., 2001). Mannitol may act as a hapten binding to proteins and acting through an IgE-mediated mechanism.(Hedge, 2004)

\section{Erythritol}

Erythritol is also a sugar alcohol used for sweetening of foods and beverages. Yunginger et al., 2001, Shirao et al., 2013 and Harada et $a l ., 2016$ have all reported of allergic reactions due to the ingestion of erythritol-containing foods and beverages. The mechanism of action of erythritol in provoking allergic reactions remains unknown, but the hapten hypothesis does not seem to be the complete explanation (Harada et al., 2016).

\section{Maltitol}

Maltitol, a sugar alcohol, contained in a candy was implicated as the cause of pharyngeal edema in a single case report based on a positive basophil activation test (Rodriguez et al., 2017).

The increase consumption of processed foods results in the increase in the use of food additives. Any novel food additives must undergo extensive safety evaluation prior to 
their approval. However, there has been a considerable controversy in regards to the risks and benefits of food additives. Concerns have been expressed about adverse reactions associated with food additives in sensitive individuals. The prevalence of these reactions is rather low in contrary to insights of the general public. The best strategic approach for management of food additive hypersensitivity is complete avoidance of the offending foods. Adequate information about the food additives, along with the types of food in which it may be found and the various terms that are used to identify them on an ingredient statement is crucial. Label reading is extremely essential for individual who are hypersensitive. Ingredient label reading for all products always should be repeated every time before purchase of foods. The responsibility of a food processor is in declaring food additives in the product on the label.

\section{References}

Allen DH, Delohery J, Baker G (1987) Monosodium Lglutamate-induced asthma. J Allergy Clin Immunol 80:530537

Anibarro B, Seone J, Vila C, et al., Occupational asthma induced by inhaled carmine among butchers. Occup Med Environ Health 2003; 16:133-7.

Ardern KD, Ram FS. Tartrazine exclusion for allergic asthma. Cochrane Database Syst Rev 2001; (4): CD000460.

Asero R. Chronic generalized pruritus caused by nitrate intolerance. J Allergy Clin Immunol 1999; 104:1110-11.

Asero R. Perennial rhinitis induced by benzoate intolerance. J Allergy Clin Immunol 2001; 107:197.

Belchi-Hernandez J, Florido-Lopez JF, EstradaRodriguez JL, et al., Sulfite-induced urticaria. Ann Allergy 1993;71:230-2.

Botterweck, A.A., Verhagen, H., Goldbohm, R., Kleinjans, J., and van den Brandt, P. (2000). Intake of butylated hydroxyanisole and butylated hydroxytoluene and stomach cancer risk: results from analyses in the Netherlands Cohort Study. Food and Chemical Toxicology, 38, 599-605.

Bridts $\mathrm{CH}$, Ebo DG, DeClerck LS, et al., Anaphylaxis due to the ingestion of guar gum. J Allergy Clin Immunol 2002; 109: S221.

Bush RK, Taylor SL, Busse W. A critical evaluation of clinical trials in reactions to sulfites. J Allergy Clin Immunol 1986; 78: 191-202.

Calogiuri GF, Muratore L, Nettis E, et al., Immediate-type hypersensitivity reaction to mannitol as drug excipient (E421): a case report. Eur Ann Allergy Clin Immunol 2015; 47:99-102.

Catherine, R., Catherine, C., Christophe, D. (1996). Allergy To Soy Lecithin In A Child. Journal of Pediatric Gastroenterology \& Nutrition, 22, 328329.

Chung K, Baker JR Jr, Baldwin JL, et al., Identification of carmine allergens among three carmine allergy patients. Allergy 2001;56:73-7.

Clemmensen O, Hjorth N. Perioral contact urticaria from sorbic acid and benzoic acid in a salad dressing. Contact Dermatitis 1982; 8:1-6.

Danoff D, Lincoln L, Thomson DMP, et al., Big Mac attack. N Engl J Med 1978;298:1095-6.

Descote, J. (1996). Human Toxicology, 1st edn. Elsevier, chapter 5, 263.

Devlin J, David TJ (1992) Tartrazine in atopic eczema. Arch Dis Child 67(6):709-711

Ebo DG, Ingelbrecht $\mathrm{S}$, Bridts $\mathrm{CH}$, et al., Allergy for cheese: evidence for an IgEmediated reaction from the natural dye annatto. Allergy 2009; 64: 1558-60.

Ehlers I, Niggemann B, Binder C, et al., Role of nonallergic hypersensitivity reactions in children with chronic urticaria. Allergy 1998; 53:1074-7.

Elhkim, M.O., Heraud, F., Bemrah, N., Gauchard, F., Lirino, T., Lambre,C. et al., (2007). New consideration regarding 
the risk assessment on Tartrazine. An Update Toxicological Assessment, Intolerance Reactions and Maximum Theoretical Daily Intake in France. Regulatory Toxicology and Pharmology,47,311.

Fahrenholz JM, Smith KM. Adverse reactions to benzoates and parabens. In: Metcalfe DD, Sampson HA, Simon RA, editors. Food allergy - Adverse reactions to foods and food additives. Boston: Blackwell Scientific; 2008. p. 394-402.

Feketea G, Tsabouri S. Common food colorants and allergic reactions in children: Myth or reality? Food Chem 2017; 230: 57888.

Fuglsang G, Madsen C, Halken S. Adverse reactions to food additives in children with atopic symptoms. Allergy 1994;49:39.

Fuglsang, G., Madsen, C., Saval, P., \& Østerballe, O. (1993). Prevalence of intolerance to food additives among Danish school children. Pediatric Allergy and Immunology, 4(3), 123129.

Garriga MM, Berkebile C, Metcalfe DD. A combined single-blind, double-blind, placebo-controlled study to determine the reproducibility of hypersensitivity reactions to aspartame. J Allergy Clin Immunol 1991; 87:821-7.

Garriga MM, Metcalfe DD. Aspartame intolerance. Ann Allergy 1988; 61:63-9.

Geha R, Buckley CE, Greenberger $\mathrm{P}$, et al., Aspartame is no more likely than placebo to cause urticaria/angioedema: results of a multicenter, randomized, double-blind, placebo-controlled, crossover study. J Allergy Clin Immunol 1993; 92:513-20.

Golightly LK, Smolinske S, Bennett ML, et al., Pharmaceutical excipients. Adverse effects associated with inactive ingredients in drug products (Part I). Med Toxicol 1988; 3:128-65.

Goodman, D.L., McDonnell, R.W., Nelson, H.S., Vaughan, T.R., Weber, R.W. (1990). Chronic Urticaria Exacerbated by The Antioxidant Food Preservatives, Butylated Hydroxyanisole (BHA) And Butylated Hydroxytoluene (BHT) Journal of Allergy and Clinical Immunology, 86, 570-571.

Greenhawt M, McMorris M, Baldwin J. Carmine hypersensitivity masquerading as azithromycin hypersensitivity. Allergy Asthma Proc 2009; 30:95-101.

Gultekin, F., Dogue, D.K. (2013). Allergic And Immunologic Reactions To Food Additives. Clinical Reviews in Allergy \& Immunology,45,6-24.

Harada N, Hiragun M, Mizuno M, et al., A case of erythritol allergy studied by basophil histamine release and CD203c expression in vitro in addition to a challenge test in vivo. J Investig Allergol Clin Immunol 2016; 26:135-6.

Harrison DA, Smith AG. Concomitant sensitivity to sodium metabisulfite and clobetasone butyrate in Trimovate cream. Contact Dermatitis 2002;46:310.

Hawkins CA, Katelaris CH. Nitrate anaphylaxis. Ann Allergy Asthma Immunol 2000; 85:74-6.

Hegde VL, Venkatesh YP. Anaphylaxis to excipient mannitol: evidence for an immunoglobulin E-mediated mechanism. Clin Exp Allergy 2004; 34:1602-9.

Hino, H., Kasai, S., Hattori, N., and Kenjo, K. (2000). A case of allergic urticaria caused by erythritol. The Journal of Dermatology, 27(3), 163-165.

Ibero M, Eseverri JL, Barroso C, Botey J (1982)Dyes, preservatives and salicylates in the induction of food intolerance and/or hypersensitivity in children. Allergol Immunopathol 10(4): 263-268

Infante S, Lopez-Matas MA, Carnes C, et al., Allergy reaction mediated by Gal $\mathrm{d} 4$ (lysozyme) after induction of tolerance with egg. Ann Allergy Asthma Immunol 2014;113:482-5.

Inomata $\mathrm{N}$, Osuna $\mathrm{H}$, Fujita $\mathrm{H}$, Ogawa $\mathrm{T}$, Ikezawa Z (2006) Multiple chemical sensitivities following intolerance to azo 
dye in sweets in a 5-year-old girl. Allergol Int 55(2):203-205

Jain SS, Green S, Rose M. Anaphylaxis following intravenous paracetamol: the problem is the solution. Anaesth Intensive Care 2015; 43:779-82.

James C, Horbal J, Tcheurekdjian $\mathrm{H}$, et al., Code red: a case of anaphylaxis to a soda. Ann Allergy Asthma Immunol

Jansen JJN, Kardinaal AFM, Huijbers G, VliegBoerstra BJ, Martens BPM, Ockhuizen T. Prevalence of food allergy and intolerance in the adult Dutch population. J Allergy Clin Immunol 1994;93:446-456.

Jędrzejczyk, M., Bartnik, K., Funkowicz, M., Toporowska, K.E. (2020). Locust Bean Gum Induced FPIES In Infant. Journal of Investigational Allergology and Clinical Immunology, 30, 2-3.

Jimenez-Arnau AM, Deza G, Bauer A, et al., Contact allergy to preservatives: ESSCA results with the baseline series, 20092012. J Eur Acad Dermal Venereol 2017; 31:664-71.

Katsue, H., Higashi, Y., Baba, N., Aoki, M., \& Sakanoue, M. (2014). Allergic reaction caused by acesulfame potassium in foods. Contact dermatitis, 71(4), 251252.

Lavaud, F., Perdu, D., Prcvost, A., Vallcrand, H., Cossart, C., Passemard, F. (1994). Baker's Asthma Related To Soybean Lecithin Exposure. Allergy, 49, 159.

Liippo J, Lammintausta K. An oral challenge test with carmine (E120) in skin prick test positive patients. Eur J Allergy Clin Immunol 2015;47:206-10.

Lipton RB, Newman LC, Cohen JS, Solomon S. Aspartame as a dietary trigger of headache. Headache 1989; 29: 90-2.

Lucas CD, Hallagan JB, Taylor SL. The role of natural color additives in food allergy. Adv Food Res 2001;43:195-216.

MacGibbon, B. (1983). Adverse reactions to food additives. Proceedings of the Nutrition Society, 42(02), 233-240.

Madan V, Walker SL, Beck MH. Sodium metabisulfite allergy is common but is it relevant? Contact Dermatitis 2002;57:173-6.

Madan V, Walker SL, Beck MH. Sodium metabisulfite allergy is common but is it relevant? Contact Dermatitis 2002;57:173-6.

Madsen C. Prevalence of food additive intolerance. Hum Exp Toxicol 1994; 13 : 393-9.

Magner, J., Gerber,P. (1994).Urticaria Due To Blue Dye In Synthroid Tablets.THYROID, 4,341 .

Matiz C, Jacob SE. Systemic contact dermatitis in children: how an avoidance diet can make a difference. Pediatr Dermatol 2011; 28: 368-74.

Melgares, ML.G., Caudra, J., Martin, B., Laguna, C., Martinez, L., Alegre, V. (2007). Sensitization To Gallates: Review Of 46 Cases. Actas DermoSifiliograficas, 98, 689.

Metcalfe, D.D., Sampson, H.A., Simon, R.A. (2008) Food Allergy: Adverse Reactions to Foods And Food Additives,4th ed. Blackwell Publishing Ltd, chapter 32,388.

Mikkelsen H, Larsen JC, Tarding F (1978) Hypersensitivity reactions to food colours with special reference to the natural colour annatto extract (butter colour). Arch Toxicol Suppl (1):141143

Moneret-Vautrin DA, Einhorn C, Tisserand J. Role of sodium nitrite in histamine urticaria of dietary origin. Ann Nutr Aliment 1980; 34:1125-32.

Mueller NT, Jacobs Jr DR, MacLehose RF (2015) Consumption of caffeinated and artificially sweetened soft drinks is associated with risk of early menarche. Am J Clin Nutr. 102: 648-54.

Muthiah R, Kagen S, Zondlo A (1997) Hidden allergens in medications: allergy to acacia in Synthroid tablets. J Allergy Clin Immunol. 99: S492.

Myles I, Beakes D. (2009) An allergy to goldfish? Highlighting the labeling laws for food additives. World Allergy Org J.;2:314-16. 
National Center for Health Statistics, 2008. Food Allergy Among U.S. Children: Trends in Prevalence and Hospitalizations. CDC 10:1-3.

Neltner TG, Kulkarni NR, Alger HM, (2011) Navigating the US food additive regulatory program. Compr Rev Food Sci Food Saf. 10: 342-68.

Nettis E, Colanardi MC, Ferrannini A (2003) Suspected tartrazine-induced acute urticaria/angioedema is only rarely reproducible by oral re challenge. Clin Exp Allergy. 33:1725-9.

Niestijl-Jansen JJ, Kardinaal AF, Huijbers G. Prevalence of food allergy and intolerance in the adult Dutch population. J Allergy Clin Immunol 1993; 4:446.

Nish WA, Whisman BA, Goetz DW, et al., Anaphylaxis to annatto dye: a case report. Ann Allergy 1991;66:129-31.

Ohgiya Y, Arakawa F, Akiyama H, et al., Molecular cloning, expression, and characterization of a major 38-kd cochineal allergen. J Allergy Clin Immunol 2009; 123: 1157-62.

Pachor ML, Urbani G, Cortina P, et al., Is the Melkersson-Rosenthal syndrome related to the exposure to food additives? Oral Surgery Oral Med Oral Pathol 1989; 87:393-5

Pacor ML, Di Lorenzo G, Martinelli N, et al., Monosodium benzoate hypersensitivity in subjects with persistent rhinitis. Allergy 2004;59:192-7.

Pacor ML, Di Lorenzo G, Martinelli N, et al., Monosodium benzoate hypersensitivity in subjects with persistent rhinitis. Allergy 2004; 59:192-7.

Papanikolaou I, Stenger R, Bessof JC, et al., Anaphylactic shock to guar gum (food additive E412) contained in a meal substitute. Allergy 2007;62:822.

Park GR. Anaphylactic shock resulting from casualty simulation: a case report. J Royal Army Medical Corps 1981; 127:85-6.

Park HW, Park CH, Park SH, et al., Dermatologic adverse reactions to 7 common food additives in patients with allergic diseases: a double-blind, placebo-controlled study. J Allergy Clin Immunol 2008;121:1059-61.

Pestana S, Moreira M, Olej B (2010) Safety of ingestion of yellow tartrazine by doubleblind placebo controlled challenge in 26 atopic adults. Allergol Immunopathol 38(3):142-146

Rajan JP, Simon RA, Bosso JV. Prevalence of sensitivity to food and drug additives in patients with chronic idiopathic urticaria. J Allergy Clin Immunol Pract 2014; 2:168-71.

Ralph N, Verma S, Merry S, et al., What is the relevance of contact allergy to sodium metabisulfite and which concentration of the allergen should we use? Dermatitis 2015;26:162-5.

Ralph N, Verma S, Merry S, et al., What is the relevance of contact allergy to sodium metabisulfite and which concentration of the allergen should we use? Dermatitis 2015;26:162-5.

Ramsey NB, Tuano KTS, Davis CM, et al., Annatto seed hypersensitivity in a pediatric patient. Ann Allergy Asthma Immunol 2016;117:331-2.

Randhawa S, Bahna SL. Hypersensitivity reactions to food additives. Curr Opin Allergy Clin Immunol 2009;9:278-

Reus KEH, Houben GF, Stam M, et al., [Food additives as the cause of medical complaints: connection with asthma and anaphylaxis demonstrated only for sulfite; results of a literature study] 2000;144:1836-9.

Rodriguez Trabado A, Camara Hijon C, Magriz Trascon I, et al., A case of immediate hypersensitivity reaction to maltitol. Case Rep Med 2017; 2017:2127167.

Rodríguez Trabado, A., Cámara Hijón, C., García-Trujillo, J. A., Magriz Trascón, I., and Fernández Pereira, L. M. (2017). A Case of Immediate Hypersensitivity Reaction to Maltitol. Case Reports in medicine, 2017.

Roesch A, Haegele T, Vogt T, et al., Severe contact urticaria to guar gum included as 
a gelling agent in a local anaesthetic. Contact Dermatitis 2005;52:307-8.

Rubinger D, Friedlander M, Superstine E. Hypersensitivity to tablet additives in transplant patients on prednisone. Lancet 1978;2:689. Fotisch K, Fah J, Wuthrich $\mathrm{B}$, et al., IgE antibodies specific for carbohydrates in a patient allergic to gum arabic (Acacia senegal). Allergy 1998; 53:1043-51.

Savino F, Muratore MC, Silvestro L, et al., Allergy to carob gum in an infant. $\mathbf{J}$ Pediatr Gastroenterol Nutr 1999; 29:475-6.

Schmid P, Wuthrich B. Peranaesthetic anaphylactoid shock due to mannitol. Allergy 1992; 47:61-2.

Shaw DW. Allergic contact dermatitis from carmine. Dermatitis 2009; 20:292-5.

Shirao $\mathrm{K}$, Inoue $\mathrm{M}$, Tokuda $\mathrm{R}$, et al., "Bittersweet": a child case of erythritolinduced anaphylaxis. Allergol Int 2013; 62:269-71

Shirao, K., Inoue, M., Tokuda, R., Nagao, M., Yamaguchi, M., Okahata, H., \& Fujisawa, T. (2013). " Bitter Sweet": A Child Case of Erythritol-Induced Anaphylaxis. Allergology International, 62(2), 269-271.

Simon RA. Update on sulfite sensitivity. Allergy 1998; 53:78-9.

Stevenson DD, Simon RA, Lumry WR, et al., Pulmonary reactions to tartrazine. Pediatr Allergy Immunol 1992; 3:222-7.

Stohs SJ, Miller MJS. A case study involving allergic reactions to sulfur-containing compounds including sulfite, taurine, acesulfame potassium, and sulfonamides. Food Chem Toxicol 2013; 63:240-3.

Supramaniam G, Warner JO (1986) Artificial food additive intolerance in patients with angio-edema and urticaria. Lancet 2:907-909

Sweatman MC, Tasker R, Warner JO, et al., Oro-facial granulomatosis: response to elemental diet and provocation by food additives. Clin Allergy 1986;16:331-8.

Sweatman MC, Tasker R, Warner JO, et al.,
Oro-facial granulomatosis: response to elemental diet and provocation by food additives. Clin Allergy 1986;16:331-8

Tabar-Purroy AI, Alvarez-Puebla MJ, AceroSainz S, et al., Carmine (E-120)-induced occupational asthma revisited. J Allergy Clin Immunol 2003;111:415-19.

Tarlo SM, Dolovich J, Listgarten C. Anaphylaxis to carrageenan: a pseudolatex allergy. J Allergy Clin Immunol 1995; 95:933-6.

Taylor SL, Bush RK, Selner JC, et al., Sensitivity to sulfited foods among sulfite-sensitive subjects with asthma. J Allergy Clin Immunol 1988; 81:115967.

Taylor SL, Dormedy ES. Flavorings and Colorings. Allergy 1998; 53:80-2.

Taylor SL, Dormedy ES. The role of flavoring substances in food allergy and intolerance. Adv Food Nutr Res 1998; 42:1-44

Taylor SL, Higley NA, Bush RK. Sulfites in foods: uses, analytical methods, residues, fate, exposure assessment, metabolism, toxicity, and hypersensitivity. Adv Food Res 1986;30:1-76.

Tran, N.L., Barraj, L.M., Hearty, A.P., Jack, M.M. (2020). Tiered intake assessment for food colours. Food Additives \& Contaminants: Part A,37,1-2.

U.S. Food and Drug Administration, 2011. Exposure Estimate for FD\&C Colors for the U.S. Population

U.S. Food and Drug Administration, 2012. Questions and Answers on Monosodium Glutamate (MSG).

U.S. Food and Drug Administration, 2012.Overview of Food Ingredients, Additives \& Colors.

Veien NK, Krogdahl A. Cutaneous vasculitis induced by food additives. Acta Derm Venereol 1991; 71: 73-4.

Volonakis M, Katsarou-Katsari A, Stratigos J. Etiologic factors in childhood chronic urticaria. Ann Allergy 1992; 69:61-5.

Warsaw EM, Maibach HI, Taylor JS, et al., North American contact dermatitis 
group patch test results: 2011-2012. Dermatitis 2015; 26:49-59.

Weber RW, Hoffman M, Raine DA Jr, et al., Incidence of bronchoconstriction due to aspirin, azo dyes, non-azo dyes, and preservatives in a population of perennial asthmatics. J Allergy Clin Immunol 1979;64:32-7

Worm M, Ehlers I, Sterry W, et al., Clinical relevance of food additives in adult patients with atopic dermatitis. Clin Exp Allergy 2000; 30: 402-14

Wuthrich B, Kagi MK, Hafner J. Disulfiteinduced acute intermittent urticaria with vasculitis. Dermatology 1993;187:290-2.

Wuthrich B, Kagi MK, Stucker W. Anaphylactic reactions to ingested carmine (E120). Allergy 1997;52:1133-7.

Wuthrich B. Sulfite additives causing allergic or pseudo-allergic reactions. In: Miyamoto T, Okuda M, editors. Progress in allergy and clinical immunology. Seattle: Hogrefe \& Huber; 1992. p. 339-44.

Yamakawa Y, Oosuna H, Yamakawa T, et al.,
Cochineal extract-induced immediate allergy. Journal of Dermatology 2009; 36:72-4.

Yim E, Baquerizo Nole KL, Tosti A. Contact dermatitis caused by preservatives. Dermatitis 2014; 25:215-31.

Young E, Patel S, Stoneham M, et al., The prevalence of reaction to food additives in a survey population. J Royal Coll Physicians Lond 1987;21:241-7.

Young E, Patel S, Stoneham M, et al., The prevalence of reaction to food additives in a survey population. $\mathrm{J} R$ Coll Physicians Lond 1987; 21:241-247.

Yunginger JW, Jones RT, Kita H, et al., Allergic reactions after ingestion of erythritolcontaining foods and beverages. J Allergy Clin Immunol 2001; 108:650.

Zuberbier, T., Edenharter, G., Worm, M., Ehlers, I., Reimann, S., Hantke, T., Niggemann, B. (2004). Prevalence of adverse reactions to food in Germany - a population study. Allergy, 59(3), 338345.

\section{How to cite this article:}

Eram S. Rao, Rizwana, C. Lalmuanpuia, G. Aparajita and Prateek, K. 2021. Food Additives and Hypersensitivity: A Review. Int.J.Curr.Microbiol.App.Sci. 10(02): 1697-1717. doi: https://doi.org/10.20546/ijcmas.2021.1002.201 